\title{
The effect of alternative forms of hunting on the social organization of two small populations of lions Panthera leo in southern Africa
}

\author{
Andrei Snyman, Craig R. Jackson and Paul J. Funston
}

\begin{abstract}
African lion Panthera leo populations have declined as a result of various anthropogenic factors, and most extant populations are small, which further compromises their persistence. Lions in unfenced areas are more exposed to illegal hunting, snaring and poisoning, and populations in fenced reserves are subject to population control by removal of selected individuals from particular age and sex classes. During 2000-2011 19 lions from the mostly unfenced Northern Tuli Game Reserve in Botswana were shot, snared or poisoned. By contrast, only one lioness was shot outside the fenced Venetia Limpopo Nature Reserve $10 \mathrm{~km}$ away, in South Africa, where 29 lions were trophy hunted or culled. We found that the mean population size, sex ratio and litter size were the same for both reserves but population density, pride size and cub survival rate were significantly higher in the fenced reserve. The size of the population in Northern Tuli was constrained by a high rate of indiscriminate anthropogenic mortality, with $94.7 \%$ of adult mortality occurring outside the reserve. The different forms of anthropogenic suppression in evidence at the two reserves resulted in different population-level responses, which will ultimately affect population viability. As conservation strategies are attempting to remove fences and establish larger conservation areas, this study indicates how fences can influence population dynamics in areas where human presence threatens large carnivores.
\end{abstract}

Keywords Carnivore, demography, human-wildlife conflict, hunting, lion, Panthera leo, social structure, trophy hunting

\section{Introduction}

Populations of large carnivores are increasingly threatened (Woodroffe, 2000), with loss of habitat (Hanski, 2005), depleted prey bases (Woodroffe, 2000), and persecution by livestock farmers (Woodroffe, 2000; Treves

ANDREI SNYMAN (Corresponding author) School of Natural Resources, University of Nebraska, Lincoln, Nebraska 68583-0961, USA

E-mail andrei.snyman@gmail.com

CRAIG R. JACKSON Department of Biology, Norwegian University of Science and Technology, Trondheim, Norway

Paul J. Funston Panthera, Kongola, Namibia

Received 22 February 2013. Revision requested 22 May 2013

Accepted 9 September 2013. First published online 11 August 2014.
\& Karanth, 2003; Woodroffe \& Frank, 2005; Holmern et al., 2007). Most viable populations of large carnivores in Africa are now restricted to protected areas (Bauer \& Van Der Merwe, 2004; Hayward \& Kerley, 2009). Populations of African lions Panthera leo have been particularly affected, with an estimated 32,000-35,000 free-ranging lions remaining in Africa, and protected areas are necessary to ensure their persistence (IUCN, 2013; Riggio et al., 2013). However, populations in protected areas are still exposed to legal and illegal hunting, road kill, poisoning and snaring (Woodroffe \& Ginsberg, 1998; Woodroffe, 2000), which compromise their viability and likelihood of survival.

Growth and stability of lion populations are largely determined by social and ecological factors such as density, tenure of coalitions of residential male lions, the number of females in a pride, intergroup competition, group territoriality, and prey availability (Van Orsdol, 1984; Packer et al., 1990, 2005; Mosser \& Packer, 2009). Frequent removal of resident males may influence successful reproduction, either through factors such as infanticide or through reproductive suppression until social stability within the pride is restored (Smuts, 1982; Whitman \& Packer, 1997). The removal of adult females, the main breeding units of a pride, can also influence reproduction and population growth as larger groups have higher rates of reproductive success and tend to gain access to the best-quality habitats (Packer et al., 1988; Loveridge et al., 2007; Mosser \& Packer, 2009). The loss of cubs and subadults affects population size and future reproductive potential.

Many lion populations are restricted to small reserves that are geographically isolated from each other (Bauer \& Van Der Merwe, 2004; Slotow \& Hunter, 2009). This introduces further difficulties for conservation managers, as small populations are slower to recover from stochastic events and genetic diversity is often limited (Hayward et al., 2007). In southern Africa in particular many small populations have been fenced in an attempt to allow lions to persist in a human-dominated landscape (Hayward \& Kerley, 2009; Packer et al., 2013). In the absence of anthropogenic threats lion populations have the potential to increase rapidly (Kettles \& Slotow, 2009), and therefore managers must intervene to limit population growth in small, isolated reserves (Slotow \& Hunter, 2009). In unfenced reserves animals may attempt to disperse as population density increases but these animals are usually killed when surrounding land uses are incompatible with large predators (Woodroffe \& Frank, 2005). 


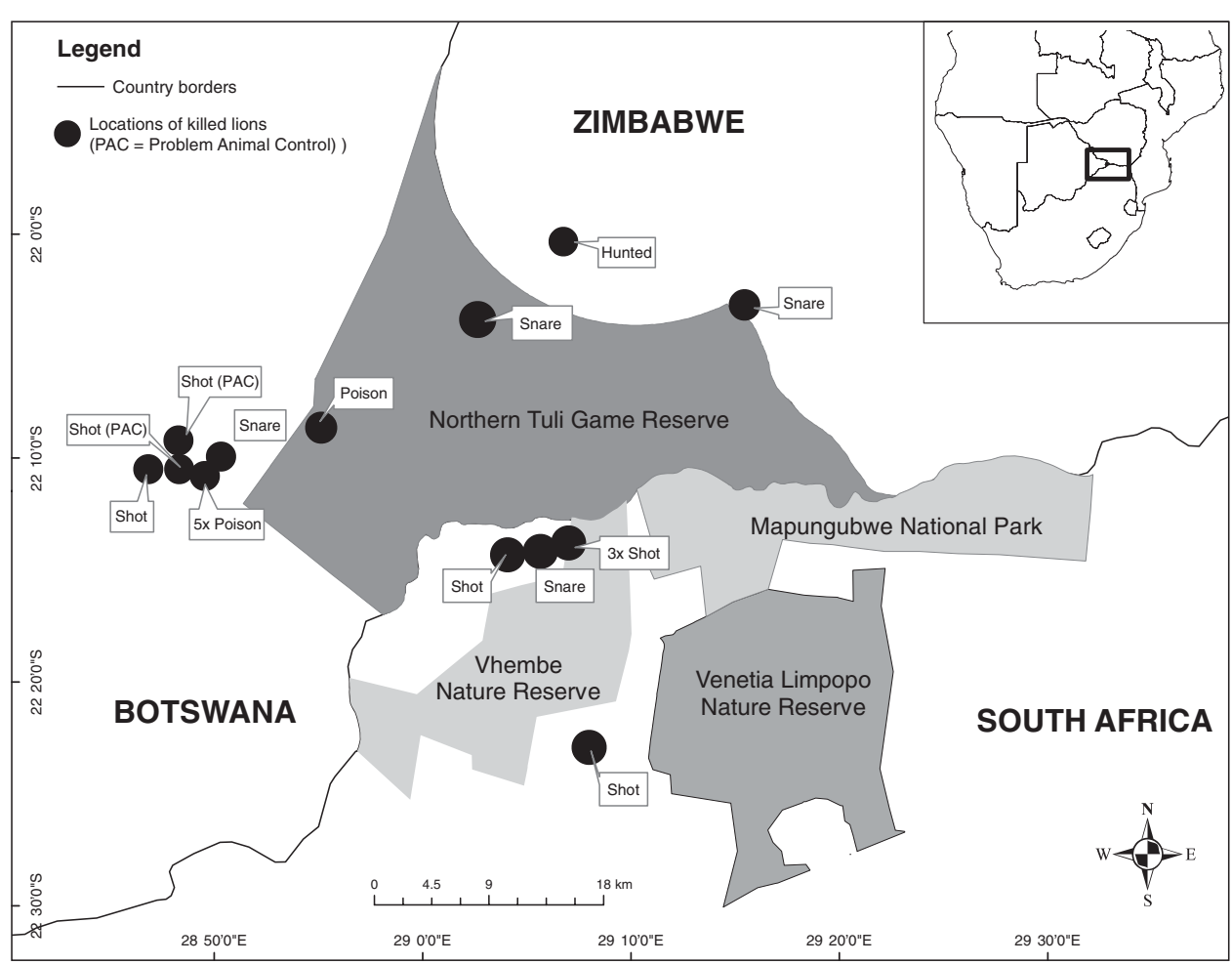

FIg. 1 The Northern Tuli Game Reserve in Botswana and the Venetia Limpopo Nature Reserve in South Africa. The locations where lions Panthera leo from the unfenced Northern Tuli Game Reserve were killed during 2000-2011 are marked on the map.
Population control methods in fenced reserves may include culling, contraception, translocation and male vasectomies (Kettles \& Slotow, 2009; Slotow \& Hunter, 2009). As an alternative, trophy hunting is sometimes used as a management tool, with the added benefit of generating revenue for protected areas. Lions are highly sought after by trophy hunters and hunting is permitted in several African countries. Although this form of harvesting is typically conducted under the guise of sustainable utilization, the selective removal of individuals has been reported to have several negative effects, including population decline (Loveridge et al., 2007), distorted social organization (Yamazaki, 1996) and distorted sex ratios (Creel \& Creel, 1997; Loveridge et al., 2007). Perturbations are more evident in smaller and geographically isolated prides, which are more vulnerable to takeovers, resulting in lower reproductive success and increased vulnerability to kleptoparasitism (Packer et al., 1988). The preference of trophy hunters for large adult males may negatively affect population dynamics (Whitman et al., 2004).

In contrast to trophy hunting, illegal killing of lions in and around unfenced reserves is predominantly indiscriminate, such as when individuals are caught in snares or exterminated by livestock owners (Woodroffe \& Frank, 2005). The effects on social organization, growth rate and survival may therefore differ from those arising from selective harvesting.

It is important for conservation managers to understand how lion population dynamics respond to these various forms of anthropogenic mortality. Here we report our findings for two small populations of lions occurring only 10 $\mathrm{km}$ apart, one exposed to legal hunting as a form of population control (in a fenced reserve) and the other to illegal persecution (in a largely unfenced reserve). Taking prey availability into account we assess the mean pride size, number of adult females per pride, cub survival rate, and population growth rate, size and density in the two reserves. We then consider the relative influence of different types of human-induced mortalities on each population.

\section{Study area}

The Northern Tuli Game Reserve and the Venetia Limpopo Nature Reserve are two privately owned reserves located c. $10 \mathrm{~km}$ apart in southern Africa (Fig. 1). The Northern Tuli Game Reserve $\left(720 \mathrm{~km}^{2}\right)$ is in south-east Botswana, bordering Zimbabwe and South Africa. The western boundary of the Reserve is game-fenced and the southern boundary, bordering South Africa, has a poorly maintained fence (total fence length c. $86 \mathrm{~km}$ ). These fences do not represent a significant barrier to the movement of large predators, and wild dogs Lycaon pictus, cheetahs Acinonyx jubatus and lions having been recorded traversing the fences (Jackson et al., 2012). The south-western, northern and eastern boundaries (c. $71 \mathrm{~km}$ ) are unfenced. The movement of carnivores between the Reserve and surrounding areas is thus largely unrestricted. No form of lion population control or management was implemented in the Reserve during the study period. 
The Venetia Limpopo Nature Reserve $\left(330 \mathrm{~km}^{2}\right)$ is situated in the far north of South Africa, close to the border with Botswana and Zimbabwe. It is entirely fenced with high-quality electrified predator-proof fencing, which is inspected daily. Safari hunting and euthanasia were the only forms of lion population control implemented here during the study. No introductions were ever made into the lion population in the Reserve.

These two reserves are scheduled to become part of the Greater Mapungubwe Transfrontier Conservation Area, which will also incorporate other reserves in the area.

\section{Methods}

Historical records indicate that lions have been present in the Northern Tuli Game Reserve for many decades, and according to early reports the lion population has been persecuted, with at least 150 lions killed during the $1950 \mathrm{~s}$ (Lind, 1974). By the late 1960s lions were almost extirpated from the Reserve (McKenzie, 1990) but the population began to recover in the early 1970s (Lind, 1974). Since 1993 game rangers have completed a sightings datasheet after every game drive, providing a detailed long-term dataset. We analysed 15,067 records collected in the Northern Tuli Game Reserve during September 2000-December 2011.

The Venetia Limpopo Nature Reserve comprises former livestock farms and was designated a nature reserve in the early 1990s. It was recolonized by seven lions from surrounding areas (Cotterill, 1996), and by 1994 reserve managers estimated that there were 12-15 resident lions. By 1996 the number had increased to 22 (Cotterill, 1996). Since then researchers and Reserve management staff have monitored the population closely. Trophy hunting has been carried out since 2000 to regulate population growth and reduce the number of lions over time. Initially lion hunting was indiscriminate and 14 lions (10 males and four females) were shot during 2000-2003. In 2003 a continuous and detailed monitoring programme was introduced by Funston \& Janse Van Rensburg (2003), after which only specific individuals were removed from the population. Safari hunting to manage prey populations within the fenced reserve was also common practice.

We use monitoring data for 2000-2011 to compare and contrast demographic parameters of the lion populations within each reserve. Although carnivore density may vary significantly between different ecosystems, it is correlated with the biomass of preferred prey species present (Bertram, 1975; Hayward et al., 2007; Hayward \& Kerley, 2008). To control for potential population-level effects arising from variations in prey availability we use prey census data to calculate the available biomass of the lion's preferred prey species according to Hayward et al. (2007). Preferred prey species include zebra Equus burchelli, wildebeest Connochaetes taurinus, giraffe Giraffa camelopardalis, gemsbok Oryx gazella and eland Taurotragus oryx. Eland are functionally similar to buffalo Syncerus caffer and serve as a substitute for buffalo in the lion's diet, given that buffalo are not present in either of the study areas.

\section{Results}

During 2005-2011 there were 19 reported incidences of lion mortality in the Northern Tuli Game Reserve: 11 (58\%) adults ( 5 male, 6 female) and eight (42\%) subadults (3 male, 5 female). These deaths resulted from illegal killings $(n=6)$, trophy hunting in Tuli Circle $(n=1)$, poisoning $(n=6)$, snaring $(\mathrm{n}=4)$ and problem-animal control $(\mathrm{n}=2)$. A further 19 lions (12 males and 7 females) dispersed from the area during 2000-2011. They were not seen again and it is not known whether or not they survived. In the Venetia Limpopo Nature Reserve we recorded 20 cases of adult mortality (11 males, 9 females) and 10 cases of subadult mortality (4 males, 6 females) during 2005-2011. The majority $(60 \%, n=18)$ of these were trophy hunted, $37 \%(n=11)$ were euthanized during a management intervention in 2009 to reduce the population size, and one lion was found dead outside the borders of the Reserve. In Northern Tuli the majority of recorded mortalities $(94.7 \%, \mathrm{n}=18)$ occurred outside the Reserve, whereas in Venetia only one mortality was recorded outside the Reserve (Fig. 1) and the other mortalities were recorded within its borders.

Based on the methods of Hayward et al. (2007) the lion populations of Nothern Tuli and Venetia were estimated at 73 and 21, respectively, giving estimated population densities of 0.101 and 0.064 lions per $\mathrm{km}^{2}$, respectively. Although the mean population size was similar in both reserves for the duration of the study (18.6 \pm SE 1.0 in Northern Tuli, $16.5 \pm \mathrm{SE} 1.8$ in Venetia) there was a significant difference $(U=43$; $\mathrm{P}<0.05$, Mann-Whitney $U$-Test $)$ in population density between the reserves (mean 2.6 lions per $100 \mathrm{~km}^{2}$ in Northern Tuli and 5.0 lions per $100 \mathrm{~km}^{2}$ in Venetia; Fig. 2a). This was despite the significantly higher prey biomass in Northern Tuli $\left(1,216 \pm\right.$ SD $176.6 \mathrm{~kg}$ per $\left.\mathrm{km}^{2}\right)$ compared to Venetia $\left(375 \pm\right.$ SD $18.3 \mathrm{~kg}_{\text {per km}}^{2} ; U=0 ; \mathrm{P}=0.016$, MannWhitney $U$-Test). Population growth rates for both reserves were low (Northern Tuli, 1.1 \pm SE 0.1, range 0.6-1.8; Venetia, $1.0 \pm$ SE 0.1 , range $0.2-1.6$ ) and did not vary substantially over the study period (Fig. 2 b).

In addition to these population differences the total number of individuals in each pride differed significantly between Northern Tuli (4.7 \pm SE 0.4, range 2-12) and Venetia (7.4 \pm SE 1.1, range 3-10; $U=10.5 ; \mathrm{P}<0.05$, Mann-Whitney $U$-Test). The mean number of adult females per pride was also significantly different $(U=13$; $\mathrm{P}<0.05$, MannWhitney $U$-Test) between Northern Tuli (2.9 \pm SE 0.2, range 2-4) and Venetia (2.1 \pm SE 0.1, range 2-3).

During the study 23 litters of cubs $(n=60)$ were born in Northern Tuli and 11 litters $(n=28)$ were born in Venetia. 

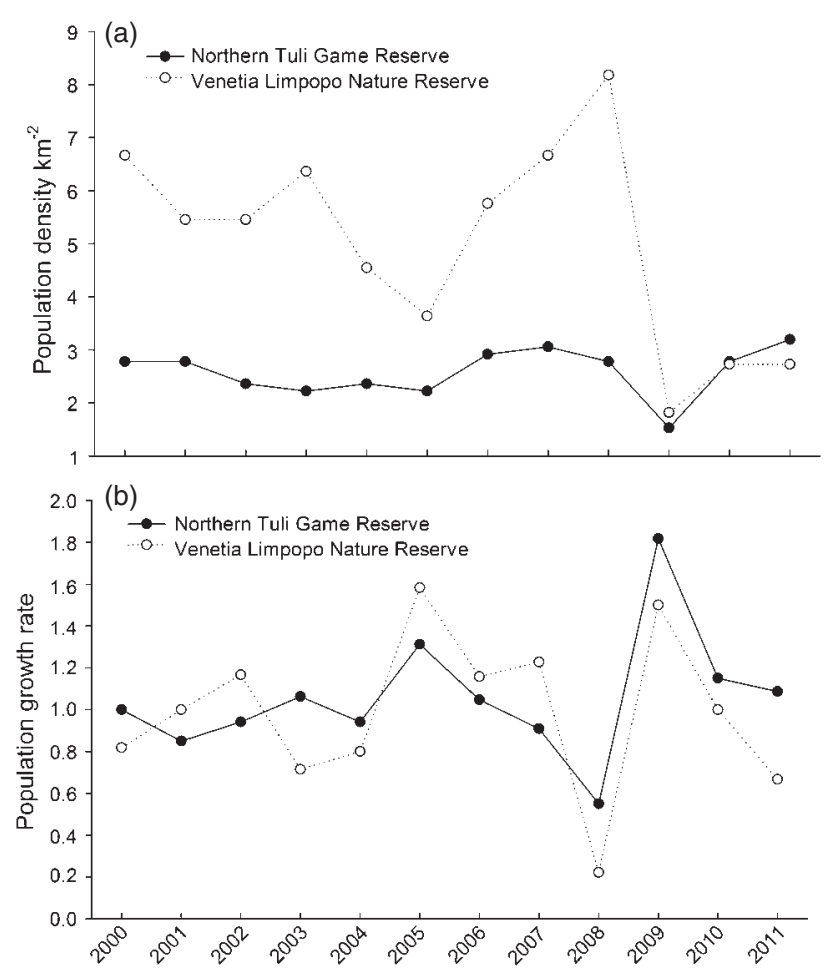

FIG. 2 Lion population density (a) and growth rates (b) in the Northern Tuli Game Reserve and Venetia Limpopo Nature Reserve (Fig. 1) during 2000-2011.

In Northern Tuli eight cubs died before their sex could be determined, $81 \%(n=48)$ reached 12 months of age, $65 \%$ $(\mathrm{n}=38)$ reached 18 months, and 55\% $(\mathrm{n}=32)$ reached 24 months. The cub survival rate in Venetia was significantly higher, with $96 \%(\mathrm{n}=27)$ of cubs reaching 12 months of age $\left(\chi^{2}=5.13\right.$, df $=1, \mathrm{P}<0.05$ with Yates correction), $93 \%(\mathrm{n}=26)$ reaching 18 months, and $86 \%(\mathrm{n}=24)$ reaching 24 months (Fig. 3). There was no significant difference ( $U=102 ; \mathrm{P}>0.05$, Mann-Whitney $U$-Test $)$ in the mean litter size between Northern Tuli (2.6 \pm SE 0.2, range 1-4) and Venetia (2.8 \pm SE 0.2, range 1-4).

On average, adults comprised $69 \%$ of the Northern Tuli population, with adult females outnumbering males by $1.7: 1$. Similarly in Venetia adults comprised $77 \%$ of the population, with females again outnumbering males by $1.7: 1$ (Table 1). The sex ratio among subadult lions in Northern Tuli was skewed slightly in favour of females (M: F, $1: 1.4)$ and in Venetia was skewed slightly in favour of males $(\mathrm{M}: \mathrm{F}$, 1:0.9; Table 1). These differences were not significant $\left(\chi^{2}=0.60, \mathrm{df}=1, \mathrm{P}>0.05\right)$. The sex ratio amongst cubs was similar in both reserves $(\mathrm{M}: \mathrm{F}, 1: 0.9)$.

\section{Discussion}

The importance of small lion populations

In a comprehensive inventory of lion populations, Bauer \& Van Der Merwe (2004) documented 89 extant populations

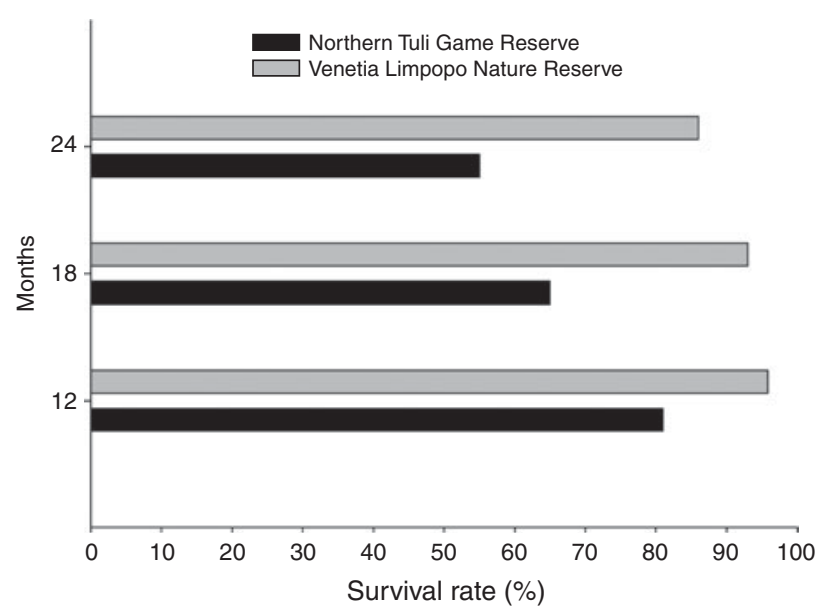

Fig. 3 Mean survival rates for lion cubs in the Northern Tuli Game Reserve and Venetia Limpopo Nature Reserve (Fig. 1) during 2000-2011.

across Africa (for which population estimates were available). Of these populations 50 have an estimated 100 or fewer lions, with 33 populations having 50 or fewer. With so many small and isolated lion populations, the conservation and protection of these populations are important. Populations such as those in the Northen Tuli Game Reserve and the Venetia Limpopo Nature Reserve are exposed to a variety of sources of anthropogenic mortality. In Northern Tuli, which is largely unfenced, most human-caused lion mortalities are as a result of illegal activities such as snaring, poisoning and shooting, whereas in Venetia they are almost entirely legal and precipitated by management to control the population within the fenced reserve. Most of the lion mortalities from the Northern Tuli population occurred close to the Reserve boundary, indicating the intensity of edge effects in the absence of predator-proof fencing (Fig. 1). Lion numbers along the Shashe River, the boundary between Botswana and Zimbabwe, reportedly declined during 20002009, mainly as a result of snaring (B. Petty, pers. comm.).

\section{Effects of different forms of anthropogenic mortality}

The lion populations studied responded differently to different causes of mortality. The population density of the Northern Tuli lions was markedly lower than predicted based on prey biomass (Hayward et al., 2007). This was associated with lower cub survival and significantly smaller prides, despite there being more adult females per pride in Northern Tuli. During 2000-2003 unselective hunting in the Venetia Limpopo Nature Reserve disrupted the population to such an extent that prides were absent during this period. Thus, excessively high and unselective mortality led to the breakdown of the fundamental fabric of lion society. Prides began to form again after indiscriminate and intense trophy hunting was halted in 2004 in favour of a more selective approach. These findings are useful for interpreting lion population structure in other areas. 
TABLE 1 Sex and age structure of lion Panthera leo populations in the Northern Tuli Game Reserve, Botswana, and Venetia Limpopo Nature Reserve, South Africa (Fig. 1), during 2000-2011.

\begin{tabular}{|c|c|c|c|c|c|c|c|c|c|c|}
\hline \multirow[b]{3}{*}{ Year } & \multicolumn{5}{|c|}{ Northern Tuli Game Reserve } & \multicolumn{5}{|c|}{ Venetia Limpopo Nature Reserve } \\
\hline & \multicolumn{2}{|l|}{ Adult } & \multicolumn{3}{|c|}{ Subadult } & \multicolumn{2}{|l|}{ Adult } & \multicolumn{3}{|c|}{ Subadult } \\
\hline & Males & Females & Males & Females & Sex ratio $(M: F)$ & Males & Females & Males & Females & Sex ratio $(M: F)$ \\
\hline 2000 & 1 & 2 & 1 & 1 & $1: 1.5$ & 1 & 2 & & & $1: 2$ \\
\hline 2001 & 4 & 4 & & & $1: 1$ & 5 & 5 & 3 & & $1: 0.6$ \\
\hline 2002 & 3 & 3 & & & $1: 1$ & 5 & 3 & & & $1: 0.6$ \\
\hline 2003 & 3 & 3 & & & $1: 1$ & 4 & 3 & 2 & 3 & $1: 1$ \\
\hline 2004 & 3 & 3 & 3 & 3 & $1: 1$ & 1 & 5 & 2 & 2 & $1: 2.3$ \\
\hline 2005 & 3 & 4 & 3 & 2 & $1: 1$ & 2 & 4 & & 2 & $1: 3$ \\
\hline 2006 & 1 & 3 & 2 & 2 & $1: 1.7$ & 2 & 4 & & 2 & $1: 3$ \\
\hline 2007 & 2 & 2 & 2 & 2 & $1: 1$ & 2 & 6 & 2 & & $1: 1.5$ \\
\hline 2008 & 4 & 7 & 3 & 4 & $1: 1.6$ & 2 & 6 & 2 & 1 & $1: 1.8$ \\
\hline 2009 & 3 & 7 & & & $1: 2.3$ & 1 & 2 & & & $1: 2$ \\
\hline 2010 & 1 & 7 & 1 & 5 & $1: 6$ & 1 & 2 & & & $1: 2$ \\
\hline 2011 & 4 & 9 & 1 & 3 & $1: 2.4$ & 2 & 5 & 1 & 1 & $1: 2$ \\
\hline Mean & 2.7 & 4.5 & 2.0 & 2.8 & $1: 1.6$ & 2.3 & 3.9 & 2.0 & 1.8 & $1: 1.3$ \\
\hline
\end{tabular}

Lions occurring in large, well-protected parks tend to live in prides of c. 12-15 individuals, with 4-6 adult lionesses per pride. Prides are defended by a coalition of males (Schaller, 1972; Smuts, 1976; Funston, 2011). These populations are typically close to the predicted carrying capacity (Loveridge \& Canney, 2009; Ferreira \& Funston, 2010). However, there is an increasing body of literature that indicates that in many smaller protected areas, where lions are exposed to various intense forms of anthropogenic mortality, they do not occur at predicted densities (Kiffner et al., 2009; Croes et al., 2011; Groom et al., 2014) and populations comprise smaller prides and foraging groups (Bauer, 2003; Bauer et al., 2012). These responses have been attributed to the ratios of lions to medium/large prey biomass (Bauer et al., 2008) or the effect of vegetation density (Trinkel et al., 2008). However, we suggest that the variability in group composition is more likely attributable to the combined effects of anthropogenic sources of mortality, and that once the adult segment of a lion population is reduced below a certain threshold the drivers for sociality (Packer et al., 1988; Mosser \& Packer, 2009) disappear, causing lion society to fragment. This is because prides are predominantly regulated by social factors (Van Orsdol, 1984; Packer et al., 1990, 2005), with food availability influencing these social mechanisms (Van Orsdol et al., 1985).

Our study indicates that even when a lion population has been reduced below a certain threshold, cub survival and the rates of dispersal of subadults can nevertheless be maintained at high levels. As further evidence of a threshold effect no incidences of infanticide or inter-pride mortality were reported in either population, even though large groups of lionesses were not recorded. The lower survival rate of cubs in the Northern Tuli Game Reserve is probably a result of the high density of spotted hyaena Crocuta crocuta and may have a significant effect, given the small pride sizes and lack of male coalitions. Male lions typically reach maximum reproductive success at the age of $7-8$ years (Smuts, 1978; Packer et al., 1988). However, in both reserves we noted that almost all males that mated were $<5$ years of age, often as young as 3 years. Furthermore, with relatively few adult males, we recorded several cases of mating between close relatives, such as mother and son (AS, pers. obs.). These examples indicate that processes that lead to inbreeding depression are likely to occur in lion populations affected by human persecution.

\section{Conservation implications}

Small, fragmented wilderness areas are difficult to manage and the wildlife populations inhabiting such areas are exposed to many threats that directly compromise their viability. Fencing off these areas further isolates the resident wildlife (Hayward \& Kerley, 2009). Current approaches attempt to alleviate these problems by creating large conservation areas with buffer zones and implementing conflict-mitigation initiatives (Woodroffe et al., 2005). One particular concept is that of transfrontier conservation areas, where fences between wildlife areas in two or more neighbouring countries are removed to create a larger protected area and facilitate free movement of animals, with a buffer zone between the protected areas and human settlements. Both the Northern Tuli Game Reserve and the Venetia Limpopo Nature Reserve fall within the proposed Greater Mapungubwe Transfrontier Conservation Area. Our results indicate the threats to carnivores in the area, which need to be addressed if the intended conservation goals are to be achieved. Illegal killing, poaching, problem-animal control, and loss 
of habitat are believed to be more serious threats to lion conservation than legalized safari hunting (Whitman \& Packer, 1997), as highlighted by our results. Although fences limit the movement of some species they may also provide desirable protection for lion populations when the greater landscape harbours anthropogenic threats.

\section{Acknowledgements}

We thank President Lt Gen. Ian Khama Seretse Khama and the Department of Wildlife and National Parks, Botswana, for permission to conduct our research, Mashatu Game Reserve, Pete le Roux and David Evans for extensive financial and logistical support, Tshwane University of Technology for financial support, the Northern Tuli Game Reserve and all the land owners for transversing rights, and Warwick Mostert, Rox Brummer and Bruce Petty for their personal communications. At the Venetia Limpopo Nature Reserve data were collected by De Beers staff, students of Tshwane University of Technology, employees of the Endangered Wildlife Trust, and Global Vision International Wildlife Research Expeditions staff.

\section{References}

BAUER, H. (2003) Lion conservation in West and Central Africa: integrated social and natural science for wildlife conflict resolution around Waza National Park, Cameroon. PhD thesis.

University of Leiden, Leiden, Netherlands.

Bauer, H., Nowell, K. \& Packer, C. (2012) Panthera leo. In IUCN Red List of Threatened Species v. 2014.1. Http://www. iucnredlist.org [accessed 26 June 2014].

Bauer, H. \& VAn Der Merwe, S. (2004) Inventory of free-ranging lions Panthera leo in Africa. Oryx, 38, 26-31.

Bauer, H., Vanherle, N., Di Silvestre, I. \& De Iongh, H.H. (2008) Lion-prey relations in West and Central Africa. Mammalian Biology, 73, 70-73.

BERTRAM, B.C.R. (1975) Social factors influencing reproduction in wild lions. Journal of Zoology, 177, 463-482.

Cotterill, A. (1996) Venetia-Limpopo Nature Reserve: Report on the Preliminary Lion Census. Unpublished report for the management of the Venetia Limpopo Nature Reserve.

Creel, S. \& Creel, N.M. (1997) Lion density and population structure in the Selous Game Reserve: evaluation of hunting quotas and off take. African Journal of Ecology, 35, 83-93.

Croes, B.M., Funston, P.J., Rasmussen, G., Buij, R., Saleh, A., Tumenta, P.N. \& De Ionge, H.H. (2011) The impact of trophy hunting on lions (Panthera leo) and other large carnivores in the Bénoué Complex, northern Cameroon. Biological Conservation, 144 3064-3072.

Ferreira, S.M. \& Funston, P.J. (2010) Estimating lion population variables: prey and disease effects in Kruger National Park, South Africa. Wildlife Research, 37, 194-206.

Funston, P.J. (2011) Population characteristics of lions (Panthera leo) in the Kgalagadi Transfrontier Park. South African Journal of Wildife Research, 41, 1-10.

Funston, P.J. \& Janse Van Rensburg, D. (2003) Venetia-Limpopo Lion Project: Lion Survey March 2003. Department of Nature Conservation, Tshwane University of Technology, South Africa.
Groom, R.J., Funston, P.J. \& Mandisodza, R. (2014). Surveys of lions Panthera leo in protected areas in Zimbabwe yield disturbing results: what is driving the population collapse? Oryx, 48 , 385-393.

HANSKI, I. (2005) Landscape fragmentation, biodiversity loss and the societal response. EMBO Reports, 6, 388-392.

Hayward, M.W. \& Kerley, G.I.H. (2008) Prey preferences and dietary overlap amongst Africa's large predators. South African Journal of Wildlife Research, 38, 93-108.

Hayward, M.W. \& Kerley, G.I.H. (2009) Fencing for conservation: restriction of evolutionary potential or a riposte to threatening processes? Biological Conservation, 142, 1-13.

Hayward, M.W., O’Brien, J. \& Kerley, G.I.H. (2007) Carrying capacity of large African predators: predictions and tests. Biological Conservation, 139, 219-229.

Holmern, T., Nyahongo, J. \& Røskaft, E. (2007) Livestock loss caused by predators outside the Serengeti National Park, Tanzania. Biological Conservation, 135, 518-526.

IUCN (2013) IUCN Red List of Threatened Species v. 2013.1. Http://www.iucnredlist.org [accessed 2 April 2014].

JACKsOn, C.R., McNutt, J.W. \& Apps, P.J. (2012) Managing the ranging behavior of African wild dogs (Lycaon pictus) using translocated scent marks. Wildlife Research, 39, 31-34.

Kettles, R. \& Slotow, R. (2009) Management of free-ranging lions on an enclosed game reserve. South African Journal of Wildlife Research, 39, 23-33.

Kiffner, C., Meyer, B., Mühlenberg, M. \& Waltert, M. (2009) Plenty of prey, few predators: what limits lions in Panthera leo in Katavi National Park, western Tanzania? Oryx, 43, 52-59.

Lind, P. (1974) Shasi-Limpopo Ranger's Report 1973/1974. Unpublished report for the management and landowners of the Northern Tuli Game Reserve.

Loveridge, A.J. \& Canney, S. (2009) African Lion Distribution Modeling Project. Final report. Born Free Foundation, Horsham, UK.

Loveridge, A.J., Searle, A.W., Murindagomo, F. \& Macdonald, D.W. (2007) The impact of sport-hunting on the population dynamics of an African lion population in a protected area. Biological Conservation, 134, 548-558.

McKenzie, A.A. (1990) Co-operative hunting in the black-backed jackal (Canis mesomelas schreber). $\mathrm{PhD}$ thesis. University of Pretoria, Pretoria, South Africa.

Mosser, A. \& PACKer, C. (2009) Group territoriality and the benefits of social living in the African lion, Panthera leo. Animal Behaviour, 78, 359-370.

Packer, C., Herbst, L., Pusey, A.E., Bygott, J.D., Hanby, J.P., Cairns, S.J. \& Borgerhoff Mulder, M. (1988) Reproductive success of lions. In Reproductive Success: Studies of Individual Variation in Contrasting Breeding Systems (ed. T.H. Clutton-Brock), pp. 363-383. The University of Chicago Press, Chicago, USA.

Packer, C., Hilborn, R., Mosser, A., Kissui, B.M., Borner, M., Hopcroft, G. et al. (2005) Ecological change, group territoriality, and population dynamics in Serengeti lions. Science, 307, 390-393.

Packer, C., Loveridge, A., Canney, S., Caro, T., Garnett, S.T., Pfeifer, M. et al. (2013) Conserving large carnivores: dollars and fence. Ecology Letters, 16, 635-641.

Packer, C., Scheel, D. \& Pusey, A. (1990) Why lions form groups: food is not enough. The American Naturalist, 136, 1-19.

Riggio, J., Jacobson, A., Dollar, L., Bauer, H., Becker, M., Dickman, A. et al. (2013) The size of savannah Africa: a lion's (Panthera leo) view. Biodiversity and Conservation, 22, 17-35.

Schaller, G.B. (1972) The Serengeti Lion: A Study of Predator-Prey Relations. The University of Chicago Press, Chicago, USA. 
Slotow, R. \& Hunter, L.T.B. (2009) Reintroduction decisions taken at the incorrect social scale devalue their conservation contribution: African lion in South Africa. In Reintroduction of Top-Order Predators (eds M.W. Hayward \& M.J. Somers), pp. 43-71. Wiley-Blackwell, Oxford, UK.

Smuts, G.L. (1976) Population characteristics and recent history of lions in two parts of the Kruger National Park. Koedoe: African Protected Area Conservation and Science, 19, 153-164.

Smuts, G.L. (1978) Interrelations between predators, prey, and their environment. BioScience, 28, 316-320.

Smuts, G.L. (1982) Lion. Macmillan South Africa (Pty) Ltd., Johannesburg, South Africa.

Treves, A. \& Karanth, K.U. (2003) Human-carnivore conflict and perspectives on carnivore management worldwide. Conservation Biology, 17, 1491-1499.

Trinkel, M., Ferguson, N., Reid, A., Reid, C., Somers, M. Turelli, L. et al. (2008) Translocating lions into an inbred lion population in the Hluhluwe-iMfolozi Park, South Africa. Animal Conservation, 11, 138-143.

VAn Orsdol, K.G. (1984) Foraging behaviour and hunting success of lions in Queen Elizabeth National Park, Uganda. African Journal of Ecology, 22, 79-99.

Van Orsdol, K.G., Hanby, J.P. \& Bygott, J.D. (1985) Ecological correlates of lion social organization (Panthera leo). Journal of Zoology, 206, 97-112.

Whitman, K. \& Packer, C. (1997) The effects of sport hunting on the social organization of the African lion (Panthera leo). In Proceedings of a Symposium on Lions and Leopards as Game Ranch Animals, pp. 177-183. South African Veterinary Association Wildlife Group, Onderstepoort. South Africa.
Whitman, K.L., Starfield, A.M., Quadling, H.S. \& Packer, C. (2004) Sustainable trophy hunting of African lions. Nature, 428, $175-178$.

Woodroffe, R. (2000) Predators and people: using human densities to interpret declines of large carnivores. Animal Conservation, 3 , 165-173.

Woodroffe, R. \& Frank, L.F. (2005) Lethal control of African lions (Panthera leo): local and regional population impacts. Animal Conservation, 8, 91-98.

Woodroffe, R. \& Ginsberg, J.R. (1998) Edge effects and the extinction of populations inside protected areas. Science, 280, 2126-2128.

Woodroffe, R., Thirgood, S. \& Rabinowitz, A. (2005) People and Wildlife: Conflict or Coexistence. Cambridge University Press, Cambridge, UK.

YAMAZAKi, K. (1996) Social variation of lions in a male-depopulated area in Zambia. The Journal of Wildlife Management, 60, 490-497.

\section{Biographical sketches}

Andrei Snyman is head of the Northern Tuli Predator Project in eastern Botswana. His research focuses on the behavioural ecology and population dynamics of large African carnivores, and the conservation of the species. CRAIG J A CKSON's research focuses on the ecology, behaviour and distribution of African mammals, with a specific emphasis on conservation biology. PAUL FUnSTON has worked on the behavioural ecology and conservation of African lions for over 25 years. He oversees PANTHERA's lion programme, which is built on partnerships and funding models for lion conservation projects throughout Africa. 